\title{
COVID-19, second homes, and the challenge for rural amenity areas
}

The flight to second homes, witnessed around the world, has provoked consternation in many rural communities, which fear the spread of infection and the overloading of rural health services. But for many seasonal residents, decamping to second homes - to the open spaces of the countryside or coast - makes a lot of sense, especially if children are off school and an extended summer can begin three months early. The post-COVID-19 housing market may see a turn away from flats, especially ones without balconies, and renewed interest in rural property. In this viewpoint, we speculate on the implications of the current pandemic on rural housing in amenity areas, highlighting a potential for renewed conflict between private and public interest and reflecting on the case for a planning and broader regulatory response, which not only delivers fairer housing outcomes but also protects rural communities from a new and virulent threat.

\section{The Flight}

During the COVID-19 pandemic, western countries have seen significant movements of people to areas with concentrations of second homes (see, for example, Bellafante, 2020; Rudgard, 2020; and see also Gallent, 2020, for a summary). Within a day of the Italian lockdown, 11,000 mainland residents arrived by plane or ferry in Sardinia, in transit to popular second home destinations. Early pleas by the Sardinian authorities to be allowed to close the ferry and airports went unheeded. Governments were simply taken by surprise, unsure of how they should respond. Within a week, Spanish authorities stepped up surveillance and began preventing people from travelling to second homes in Majorca - the exodus had been triggered by lockdowns elsewhere and signs that Spain would follow suit. Once new restrictions on travel were enacted, police were deployed to stem the flow. The same pattern was observed elsewhere: the prospect of lockdown saw many second home owners preparing to decamp and, anticipating restriction, they did this as quickly and as quietly as they could. Second home owners usually resident in Paris and London did exactly this, heading to the southern provinces in France and to popular second home hotspots in the UK. In the South East of England, local media reported the arrival of Londoners to the Sussex Coast, stripping the shelves of local shops and 'increasing the risk' of infection to the elderly populations of many villages. New York City has been the epicentre of the COVID-19 crisis in the US and many of its wealthier residents have sought to insulate themselves from that crisis by heading away from the city, many to Jersey Shore towns or Long Island.

\section{The Risk}

Early studies of this movement in the US have drawn a link between high concentrations of seasonal homes (now being occupied out-of-season) and rates of COVID-19 infection in some rural areas (Bangor Daily News, 2020). The fear of town-to-country spread was expressed early on. In Long Beach, a letter to residents and property owners asked people with second homes to stay where they 'primarily live: 'local health care and other emergency services are not equipped to handle a mass influx of demand which will likely overwhelm the system' (Alexander, 2020). Officials appealed for 'common sense and compassion', but many second home owners felt within their rights to move their families to 'safer locations' if they owned property, and paid local taxes on that property, elsewhere. Long Beach second home owners are referred to as 'bennies', accused of benefiting from - more than contributing to - the host communities. This is a longstanding second home debate: whether they are a curse or a blessing (Coppock, 1977). One of the owners posted on Facebook that 'people who own second homes on Long Beach Island have just as much right to use their properties as the 'real' residents of the island [...] As for calling vacation home owners bennies [...] I'd say the real bennies are the local residents who benefit from us paying full property taxes while not getting the benefit of the 
school system and basically only using local services (like garbage collection) for 3 months out of the year' (Alexander, 2020).

But during the COVID-19 crisis, the balance of curse or blessing has changed: decamping to second homes in areas under-supplied with hospitals or other medical services has been presented as a selfish act, prioritising private over public interest. This view has been reported across Europe and the US. In the UK, the spotlight has fallen on Wales, which saw a rapid influx of second home owners in the days immediately before the national lockdown. Signs appeared in many villages encouraging seasonal residents to go home, followed quickly by a national debate over the health risks being imported, mainly from over the border in England. A letter to the First Minister in late April from fifteen senior doctors called on the Welsh Government to 'make second home use illegal' during the pandemic, to prevent a second peak (BBC News, 2020).

The overloading of services, together with housing market impacts, has long been a point of contention in the second home debate. But the potential for that overloading, and its dire implications, has now been brought into much sharper relief. The debate has a new urgency, resulting in emergency restrictions and in a new conversation about the curse or blessing of second homes, which is likely to outlive the current crisis.

\section{The Drivers}

The second home exodus was a response to a unique set of circumstances - a global pandemic and unprecedented restrictions on personal freedom. It is perhaps unsurprising that those with resources have chosen to remove themselves and their families from the epicentres of the crisis. In the UK, London saw some of the earliest infections and the most rapid rise in cases. The immediate drivers of the exodus will have been fear, perceptions of greater safety elsewhere, and also access to open space that people may have otherwise been deprived of in London, especially those living in flats without private outdoor space.

The two underlying drivers are urban housing situations and multiple home-ownership. For families with children living in flats but owning relatively spacious second homes elsewhere, the decision to relocate may have been an easy one. But explaining relocation choices in terms of a link between cramped urban housing and spacious second homes is pure speculation. There is no research linking first and second home situations. The usual assumption is that only wealthier individuals have multiple properties and it follows that their first homes will be comfortable: why invest in additional housing until your primary residence fits your personal needs? However, London prices have accelerated rapidly in recent years. Owners in relatively poor London housing, or even some renters, may own second homes elsewhere. Those second homes may have provided affordable investment opportunities for households unable to get on the housing ladder in London.

But the clearest driver - the one that made the exodus possible - must be multiple property ownership. Whilst the overall rate of homeownership fell by 10 percentage points between 2007 and 2017, the number of households owning more than one property grew. By some estimates, a fifth of households in England own multiple homes, in the form of second homes or buy-to-let investments (Gallent, 2019). Housing wealth has become concentrated in fewer hands and inequality in access to the national housing resource has grown. The flight to second homes is a visible marker of housing inequality.

The Reaction 
The reaction to second homes has always been mixed. In 1999, George Monbiot painted second home owners as being amongst the 'most selfish' people on the planet (quoted in Gallent et al, 2005). Whether they are a curse or blessing for rural areas will depend on prevailing service, population and housing market realities in host communities. They can introduce new investment and confidence to communities losing population. They may replace lost or depleted social capital. But more generally, second homes concentrate in attractive, amenity-rich, locations and may suck energy from those communities. All-year-round residents may be displaced and replaced by weekenders. Local shops are heavily utilised for a few weeks and then struggle to survive for the rest of the year. Housing market impacts are fiercely contested: an abundance of higher-income buyers competing for a limited housing resource will inevitably have an inflationary impact on prices. Local home-owners may derive benefit from this, seeing the equity of their own homes grow. But first time buyers or those on lower incomes may struggle to buy their own homes: being locked out of the market in this way can mean being displaced to the nearest service centre, where privately-rented or social housing is available.

These are all very familiar characterisations of the second home 'problem'. Although ever-present, in recent years the debate has perhaps gone a little stale, being seen as an unavoidable outcome of an open market in housing and overshadowed, perhaps, by a more generalised housing crisis marked by acute concentrations of urban housing poverty. But if political reactions are anything to go by (including the reaction of Wales' First Minister), the rural second home issue is back, perhaps having become a beacon to that general crisis of housing inequality (see also Financial Times, 2020).

\section{The New Debate and Trajectories}

But the new debate is not uniformly railed against the 'selfishness' of second home ownership: rather, it places weight on both the private drivers of the exodus - questions of housing quality and personal coping strategies - and public concerns over pressure on rural services and housing, magnified by a sense in many quarters that gross inequalities need redress. These are two broad perspectives on the exodus; and linked to these perspectives are two possible trajectories for the post-COVID-19 housing market, with particular implications for rural communities.

First, recent experiences may drive different housing choices. The lack of a vaccine against the coronavirus presents the risk of future social distancing and lockdown measures being periodically reintroduced. This may have the general effect of reducing the attractiveness of homes without outdoor space, or smaller homes where it is not feasible to spend prolonged periods home-schooling children. There may never be a return to the situation faced during the last few months, but the perception of the more limited utility of smaller homes may have a lasting effect, shaping market choices. That choice effect may incentivise the purchase of second homes away from cities by wealthier households, who want to avoid being caught out by the return of similar crises in the future.

But second, anti-second home sentiment seems to have reached a new high-water-mark. Recent reporting in the Financial Times reflected on the arson campaign against the homes of seasonal residents in Wales from 1979 onwards (Financial Times, 2020). At that time, hatred of second homes was harboured by a nationalist minority. But today, in the aftermath of the lockdown (and with the presentation of second home owners as selfish 'super spreaders' in rural communities) that sentiment seems to have broadened. If prospective owners expect to feel neither welcome nor safe in hostile rural communities, then other housing market choices might be made: bigger suburban homes rather that rural boltholes.

The UK Policy Domain 
UK Policy on second homes has been all about the charging of council tax over the last twenty years. Until 2004, second home owners could claim discounts against this local tax. Indeed, the granting of those discounts provided a means of tracking second home numbers by local authority area. Gradually, many rural authorities ceased offering the discount, instead charging the full rate. Meanwhile, the UK government's attempt to promote the independent rented sector - including buy to let - started to backfire during the 2000s and was viewed by many as the direct cause of declining owner-occupation. Therefore government started to rein-in tax breaks for private landlords as a way of tempering rentier capitalism's drag on its primary political mission: supporting private owneroccupiership. Eventually, this meant not only curbing tax relief for private landlords, but levying a stamp duty surcharge on all second homes, whether rented to private tenants or not.

But neither of these liabilities - Council Tax or the SDLT surcharge - calmed the market for second homes. Relative to the investment and amenity value of owning a second home, they are generally considered small beer (by wealthy households). It is also the case that the levying of general property and service taxes on second homes generates an expectation of rights equivalent to those of permanent residents. This was certainly the case in Long Beach Island, noted above. One alternative is to enact straight bans on second homes. This has been mooted in the past, perhaps realised through the planning system, which could be used to restrict 'change of use' from primary to second home use once a threshold concentration of second home ownership has been reached in a given area. But such bans, and restrictions on private use of property, sit uneasily with prevailing free-market dogma.

So another alternative is more significant tax reform: to levy a different local tax from second homes which acknowledges the broader externalities they generate, locally and nationally, rather than simply the costs of providing local services. UK council tax is a composite service charge and land tax, hypothecated from property values. There is an argument that for second home owners the two should be uncoupled - a service charge calibrated to actual use of services plus a land tax linked to assessed property value, which can be presented as an impact charge. This happens in Italy, for example: a service charge for collecting rubbish, etc., and IMU - Imposta Municipale Unica - on land/property owned, which is higher for homes not permanently lived in. For the UK, we could conceive of an IMU equivalent set at $2 \%$ (or higher) of value - a bit higher than the Italian IMU for second homes - levied annually and all revenues collected by, and for the direct use of, the local authority. This might represent a big cost increase for many owners, but one which could easily be recouped from Airbnb lettings or avoided completely in those years where homes are let out full-time to local residents, on assured shorthold tenancies: either way, the local area benefits - from extra revenue or an extra home available for rent.

Such a change would aim to deliver more efficient use of rural housing (or any housing, anywhere), direct payment for services used, and recompense for those communities impacted by concentrations of second homes that are unused for much of the year, but heap pressure on local services during the high season.

But the case for, and impacts of, this type of tax would be bound up with the complexities of UK housing policy. A very serious and forceful impact levy could discourage the purchase of housing as second homes; it could also effectively cost social impacts, if well-designed; and it could bring tangible benefits to rural communities. But a very important support for the housing market would be gone, having a greater negative drag on property values than the new developments that local homeowners regularly oppose (Coelho et al, 2017). Also, an impact levy would have to extend to holiday lets. Reregistration of second homes as holiday lets has become a particularly contentious issue during the COVID-19 pandemic. Owners effectively dodge council tax by registering their properties as businesses (claiming that they intend to rent them out for a minimum of 140 days each year); they 
then dodge business rates by not actually renting them out, and remaining below a $£ 15,000$ taxable income threshold; and they then become eligible for the $£ 10,000$ small business loans intended to support actual small (and local) businesses during the pandemic. The extension of a levy to holiday lets might avoid this sort of outcome but could impact negatively on tourism revenue if not welldesigned: some holiday lets actually are small businesses, or income supplements for farmers. Likewise, if tourism is more generally caught up in the whirlwind of emotion against second homes then rural economies may be put at risk.

But a sudden change in policy - borne of a cathartic moment where government acknowledges the wrongs of austerity and asserts a new commitment to combat social inequality - may be less important than the interplay between new market choices and perceptions of what is now acceptable, which may reshape rural housing outcomes in some second home hotspots. Images of urban flight may give pause for thought and maybe even the opportunity for a national conversation on future housing and community rights.

\section{References}

Alexander, D. (2020) 'Jersey Shore asks Bennies, Shoobies to stay at home for COVID-19', in Jersey 101.5, 21 March 2020

Bangor Daily News (2020) 'Rural counties with many seasonal homes see more coronavirus, study say', 16 April 2020.

Bellefante, G. (2020) The rich have a cure for coronavirus: escape from New York, The New York Times, March 142020

BBC News (2020) 'Coronavirus: ban second home use, doctors tell FM', 22 April 2020

Coppock, J.T. (Ed) (1977) Second Homes: Curse of Blessing? Pergamon: London

Coelho, M., Dellepiane-Avellaneda, S., and Ratnoo, V. (2017) The political economy of housing in England, in New Political Economy, 22, 1, pp. 31-60.

Financial Times (2020) 'Second Home Wars', 25 April 2020

Gallent, N., Mace, A., and Tewdwr-Jones, M. (2005) Second Homes: European Perspectives and UK Policies, Routledge: London

Gallent, N. (2019) Whose Housing Crisis? Assets and Homes in a Changing Economy, Policy Press: Bristol

Gallent, N. (2020) COVID-19 and the flight to second homes, Town and Country Planning, May 2020

Rudgard, O. (2020) Almost 250,000 people fled London ahead of coronavirus lockdown, The Telegraph, 18 April 2020 